\title{
ELancing Motivation on Sribulancer, an Evidence from Indonesia
}

\author{
Ani Wulandari ${ }^{1}$, Talisa Qamara ${ }^{2}$, Salem Abdulaziz Mohammed Bawazir ${ }^{3}$ \\ Narotama University Surabaya \\ ani.wulandari@narotama.ac.id
}

\begin{abstract}
Lancing is a growing trend in Indonesia. More and more people opt to become eLancers due to the job and time flexibility. This paper aims to explore further the motivational factors for Indonesian eLancers to work in Sribulancer, an online platform for freelancers. Using qualitative approach, 200 semi structured interviews were conducted to eLancers in Sribulancer.com. The result exhibited eight (8) primary motivations of eLancing such as work-family balance, flexibility and autonomy, economic incentives, skills development, trust and transparency,unemployment,passion and satisfaction, networking.
\end{abstract}

Keywords: eLancing, eLancers,Sribulancer, motivation, online platform

\section{INTRODUCTION}

\section{Research Background}

This research discusses about how the world has transformed from ancient to technology based, also that the current century differs from those of previous centuries in terms of staffing models, impact of technological progress on the emergence of Freelancing, and an overview about Freelancer. In 2016, Freelancer delivered exceptional financial results with a $37 \%$ increase in revenue on the prior year to $\$ 52.7$ million. Gross Payment Volume (GPV) in 2016 was up $190 \%$ on the prior year to $\$ 666$ million. As at 31 December 2016, the Company had a strong balance sheet with cash and equivalents of $\$ 34.8$ million and no net debt This revenue growth over the last six years has been achieved through exceptional growth in marketplace jobs posted, increased efficiency and marketplace quality and increased sales of value added services. (Anual Report : 2016)

According to Global Workplace Analytics, a firm specializing in understanding emerging workplace strategies, only 2.6 percent of the US employee workforce (3.3 million people) consider home as their primary place of work. World at Work Telework Trendlines claims 79 percent of all American workers would prefer to work out of the house at least on a part-time basis. In Southeast Asia, the Philippines has seen a dramatic uptick in its number of stay-at-home workers, with Elance-oDesk acting as the main vehicle for the nation's now one million internet freelancers. From January 2010 to April 2014, the country's freelancers earned more than US\$207 million in total, which is large when taking into account the Philippines' still immature internet connectivity. [1].

In Indonesia itself according to the results of research from the global research firm Intuit in 2010, stated in its report that before 2020, traditional ways of working would no longer be the norm. Permanent employees will be replaced by project-based workers such as freelancers and part-time workers. The long-term trend to employ workers per project will continue to increase with more than 80 percent of large corporations starting to increase the use of a more flexible workforce. Furthermore, scholars need these dimensions to be able to understand the role of a technology in an individual's life, organization and the society as a whole. The research's outcome will offer interesting findings for policy makers on how to better enhance eLancing platforms; categorization of motivations would help set the stage for more sophisticated research, theory development and social impact frameworks [2].

Freelancer or e-Lancing are able to be divided into 3 different types seen from the type of work. the differences are as follows: core employees, professional freelancers and routine workers [3]. This is the basis of the differences in expertise possessed by each doer. The average e-lancing users are those from workers, student from college who have special potential in their respective fields and even career women. For those who have just jumped in this matter besides looking for experience they could also gain money, however it will depends on the level of the skills of the freelancer itself. 


\section{General Motivation in Sribulancer}

In this competitive era nowadays, resulting an increase jobless rate in developing countries like Indonesia. Nevertheless, in the era of technology, many people are are able to obtain capital, most of them is by becoming a Freelancer. It is really proven that is not too difficult to do a job as a eLancer, because the time is flexible and enable themto work anywhere is the main key of people's motivation to choose as a freelancer. The salary of freelancers is sufficient or even equal as the salary of office employees or may even exceed the salary of employees and a manager. Within this scope freelancers are increasingly skilled and innovative because they will be in capacity to generate new things in the field of work they conduct. Taking opportunities that are not seen by others. and develop it professionally. This fact based many people interested working as freelancers.

\section{Profile of Sribulancer}

As one of the biggest HR communities, Sribulancer provides the smartest solution to the job demand and work supply, particularly for digital services such as design service, website building, content making, social media marketing, SEO, translation and many more. By using Sribulancer, a client with any kind of job and time expectation in mind can easily recruit our freelancer in a very time \& cost effective way. Because of the significant increase every year, this is the reason why many people are interested want to contribute themselves to work as Freelancers in Sribulancer. Sribulancer is an online platform that connects clients (business owners/ job providers) with over 17,600+ freelancers (workers/ service providers) that are registered in human resources

community

\section{Research Objective}

The purpose of the paper is to reveal the motivation of those who work eLancing at Sribulancer.com.

\section{THEORITICAL FRAMEWORK}

\section{Human}

Capital

Theory

Human capital is defined by the OECD as the knowledge, skills, competencies and attributes embodied in individuals that facilitate the creation of personal, social and economic well-being. [5].

Human capital - the quality of the workforce - is only one factor determining economic growth. Countries can have broadly similar educational levels, but show wide variations in their pace of growth. Other factors can include demography (especially, the ratio of young to old in a population), technological innovation, openness to foreign trade, and the state of a nation's political and legal systems. But human capital does play an important role in economic growth, and it is one that can be traced back to the 19th century and the rise of mass education. Like most relationships it isn't straightforward. Instead, there's always been something of a push-me, pull you effect. Education creates a workforce capable of taking on more complex and better-paying jobs. At the same time, the existence of such jobs makes it worthwhile for students to stay on in school; eventually, all those unpaid hours in the classroom will translate into a job that compensates workers for when they were learning and not earning. [5].

Self

Determination

Theory

Self-determination theory (SDT) is a broad theory of human personality and motivation concerned with how the individual interacts with and depends on the social environment. SDT defines intrinsic and several types of extrinsic motivation and outlines how these motivations influence situational responses in different domains, as well as social and cognitive development and personality. SDT is centered on the basic psychological needs of autonomy, competence, and relatedness and their necessary role in self-determined motivation, well-being, and growth. Finally, SDT describes the critical impact of the social and cultural context in either facilitating or thwarting people's basic psychological needs, perceived sense of self-direction, performance, and wellbeing. [6]

\section{Goal Achievement Theory}

Achievement goals are "proficiency-relevant goals that a person makes an effort in success environment" [7]. They were conceptualized by Elliot and McGregor in a 2x2 framework. A 2x2 framework of achievement goal orientations has been propounded that involves mastery (e.g., motivated to comprehend the material and improve their skills) and performance (e.g., related to comparing themselves with other students) goal 
orientations. A mastery-approach (M-ap) goal orientation (i.e., a desire to maximize learning and ability development), and a mastery-avoidance (M-av) goal orientation, (i.e., a concern of losing some skills or the inability to master all the materials) are the two models that can be gained by students. Achievement goals were described by Elliot and McGregor as a 2x2 framework. [8]

\section{RESEARCH METHOD}

This chapter examine about the method of the research, how to collect the data by online, how many respondent and studying about research question. eLancing, or Internet freelancing, is spreading at an incredibly fast pace worldwide. The eLancing work environment is called a "marketplace," which is a website where individuals interested in being hired and employers looking for individuals to perform some type of work meet. eLancing allows individuals from literally anywhere in the world to sign up and complete work using the Internet for an employer who literally can also be anywhere in the world. eLancing boasts millions of users and billions of rupiahs in transactions and it involves fundamental changes in the nature of work and in the employer-worker relationship. [9].

Freelance is one the of the reflection from configuration of new organitation that bringing the new style of work. In addition it will be a great opportunity and also allows people free to work. More creative and professional the eLancer is, it will impact also to their career. Sribulancer is one of the website which is support those people want to build their career as freelancer, around 10.000 people join and work there.

\section{Research Type}

This research using qualitative methods, because the data is based on the experience of the respondent and the perspective of each person will generate different results. Each respondent will have a different performance mechanism, thus the diversity of results can be different. The process of working on expertise in each field also has different levels. this method is expected to be able to examine each difference and help find the final results. The current study is qualitative in nature because quantitative methods can't provide comprehensive data about the phenomenon (Abubakar et al., 2014).

\section{Data Collection}

Data was collected by online, the researcher distributed 1000 questionnaire to respondents and random data sampling methods were employed. The jobs were posted online on Sribulancer.com, and responses were received from 200 Indonesian freelancers. Indonesia was chosen because it is a rapidly developing country anf possesss a robust economic growth. The number of Indonesian Freelancer might increase in the few years because it is obvious that the total number of Freelancers in the world increases as well.

Sribulancer.com were analyzed based on professional work categorization. It consist of eight (8) major categories as follows:

1. Website and Development : Website UI/UX Design, Company Profile Design, E-Commerce Website, Website Maintenance (Shared and Hosting), Website Maintenance ( VPS Website), Personal Website Creation, Website or Software Bug Fixing, Slicing to HTML and Other Webiste \& Development Work.

2. Writing : Article Writing in Indonesia, Article Writing Pacakge in English, Company Profile Copywiting in Bahasa Indonesia, Company Profile Copywriting in English, Product Description Writing Package in Bahasa Indoensia, Product Description Writing Pacakge in English, Product Description Writing and Other Writing Work.

3. Design and Multimedia : Calender Design, Monthly Graphic Design, Logo Design, Pacakging Design, Flyer \& Brochure Design, Business Stationery Design, Company Profile Design, Online Banner Design.

4. Business \& Online Marketing : SEO Service/Online Marketing, Monthly Social Media Marketing, Social Media Marketing 3 Month, SEM (Google Ads, Facebook Ads, Instagram Ads), and Other Marketing Works.

5. Translation : English to Indonesia (or Vice Versa), Mandarin to Indonesia (or Vice Versa), Korean to Indoensia (or Vice Versa), Japan to Indoensia (or Vice Versa).

6. Mobile Apps Development : Mobile App Development for Android, and Mobile App Development for IOS) 
7. Video, Audio \& Photo : Food \& Baverage Photography, Catalog Photography, Product Photography, Fashion Photography, Photo Editing, Video Production, Animation Video, Other Photo Work and Other Video Work.

8. Data Entry : Input Data in Microsoft Excel, Input Data to Website, and Other Data Entry.

\section{Research Question}

The purpose of these interviews is not to produce generalizable results for all eLancers, moreover to add and increase rich qualitative data that will lead best practices in human resource activities as well as future research. The researcher distributed open-ended questionairre with question listed as follows :

1. How did you know about elancing in Sribulancer?

2. What do you think the reason of people to be involved in elancing ?

3. What is your reason to engage in elancing ?

Beside these three questions the researcher also conduct a demographic survey to the respondent regarding their sex, age, marital status, education background, and experience

\section{RESULT AND DISCUSSION}

Qualitative data - derived from for example, interviews, written open questions and pictures - are expressed in words. Consequently, the researcher cannot use statistical analysis to give meaning to the data and, therefore, needs other methods of analysis. Content analysis is one such method. [10] Content analysis is currently used in a dizzying array of fields, ranging from marketing and media studies, to literature and rhetoric, ethnography and cultural studies, gender and age issues, sociology and political science, psychology and cognitive science, and many other fields of inquiry. Additionally, content analysis reflects a close relationship with socio- and psycholinguistics, and is playing an integral role in the development of artificial intelligence. [11] Among 200 participants, most of the eLancers (98) were referred to sign-up and freelance online by their friends who have the same profession. Seventy (70) eLancers registered via Google search, they searched for freelance sites to generate extra income. Twenty five (25) joined through newsletters and, 7 via blogs and forums.

According to the demographic details, 125 respondents were males and the others are females. Two respondents were less than 20 years, 115 respondents were between 21-30 years. Eighty five interviewees aged between 31-40 years old. One hundred respondents were married. The vast number of participants possess at least bachelor's degree. Employers commonly require eLancers to make available evidence that they merit the requested rate. Thus, one of the chosen qualifications for employers is the bachelor's degree or postgraduate (Master). Eighty three respondents earn minimally 4 years of experience. Around $50 \%$ of interviewees work in IT\& Programming, while other participants are virtually equally dispersed in other occupations. Table 1 exhibit the demographic details:

Table 1: Interviewees Profile $(\mathrm{n}=200)$

Frequency Percentage

$\begin{array}{lll}\text { Gender } & & \\ \text { Male } & 125 & 62.5 \\ \text { Female } & 75 & 37.5 \\ \text { Total } & 200 & 100.0 \\ \text { Age } & & \\ 21-30 & 115 & 57.5 \\ 31-40 & 85 & 42.5 \\ \text { Total } & 200 & 100.0 \\ \text { Marital status } & & \\ \text { Single } & 100 & 50 \\ \text { Married } & 100 & 50 \\ \text { Total } & 200 & 100.0 \\ \text { Education } & & \\ \text { Some college degree } & 20 & 10\end{array}$




$\begin{array}{lll}\text { Bachelor's degree } & 160 & 80 \\ \text { Higher degree } & 20 & 10 \\ \text { Total } & 200 & 100.0 \\ \text { Work experience } & & \\ \text { 1-3 years } & 117 & 58.5 \\ \text { 4-6 years } & 83 & 41.5 \\ \text { Total } & 200 & 100.0 \\ \text { Profession } & & \\ \text { Administrative support } & 10 & 5 \\ \text { Design Multimedia } & 40 & 20 \\ \text { IT \& Programming } & 100 & 50 \\ \text { Finance \& Management } & 5 & 2.5 \\ \text { Sales/Marketing } & 15 & 7.5 \\ \text { Writing/Translation } & 30 & 15 \\ \text { Total } & 200 & 100.0\end{array}$

The motivational reasons raised amounted to eight elements from the data. Table 3 displays the background reasons of eLancers in eLancing

Table 2: Background motivations

\section{Motivations}

\begin{tabular}{|c|c|}
\hline 1. & Work-family balance, [185] \\
\hline 2. & Flexibility and Autonomy [200] \\
\hline 3. & $\begin{array}{l}\text { Economic incentives and low barrier of } \\
\text { entry[195] }\end{array}$ \\
\hline 4. & $\begin{array}{l}\text { Opportunity to develop one's creative skills } \\
\text { [190] }\end{array}$ \\
\hline 5. & $\begin{array}{l}\text { Trust and guarantee of payment after work } \\
\text { [200] }\end{array}$ \\
\hline 6. & Unemployment, equality and disability [67] \\
\hline 7. & $\begin{array}{l}\text { Higher income compare to national wage } \\
\text { [154] }\end{array}$ \\
\hline 8. & $\begin{array}{l}\text { Developing networks to open new } \\
\text { employment opportunities [200] }\end{array}$ \\
\hline
\end{tabular}

\section{Work-Family Balance}

Most of the respondents stated their pleasure with eLancing. eLancing allows them to work from home or any places. Hence, they will be able to keep the balance of time proportion between their families and friends. The samples of what the participants said in the questionnaire listed below:

"After working in a formal company for some time, I realized that full-time jobs is absorbing me too much and leave me with no privacy with family and friends. eLancing 
provides me the sense of becoming an entrepreneur somehow and thus freelance is definitely my way of life."

Flexibility, Freedom and Autonomy

Flexibility and freedom motivated eLancers to take part in eLancing. Some respondents specified that:

"...I like to work from my house; it bounces me an improved formation of opportunity, less stress and more cash..."

“...people are choosing for e-lancing as it permits them some sort of freedom in business, in terms of working hours and the work ..."

"I like freedom in freelancing...."

"...The best part about eLancing is that you could both earn income freely and work in a professional manner..."

\section{Economic Incentives \& Low Barrier of Entry}

Large percentage of interviewees said they joined eLancing activities for monetary and economic escalation. Samples of the narration are shown below:

“...I apply my talent and to get more money"

"...the cur from the commission is cheaper and more convenient, no tax and petite capital is necessary..."

“...to earn money, is my ultimate reason..."

"Because the revenues are rational for the work..."

\section{Opportunity to Develop One's Creative Skills}

Besides economical factor, eLancers also would like to develop their creative skills. Challenging and new projects will allow them to possess more creative skills, even the ones they never had before, thus eLancing also reveal their hidden potential. These are some of their testimonials:

“...to work across the globe and practice my skills on international level..."

"...to obtained experience in work with overseas employers..."

"I revealed that I am able to compose a good article with a fine language structure, I never knew that I can do such things."

“...Be paid more and grow my skills..."

\section{Trust and Guarantee of Payment after Work}

Sribulancer as eLancing platform is considered as a trusted employers by eLancers since they will be immediately paid after finishing the project, moreover the system of work is clearly displayed and regulated including the cut of commission for the eLancer that goes to Sribulancer. Some interviewees stated that:

"Accountability, and transparency on Sribulancer.com makes me feel assured of my job and payment."

"The work scheme on Sribulancer is very clear and I know that everybody get the same opportunity to apply for the job available."

"However big my contract value is, the commission for Sribulancer stays the same and that makes everything easier to understand and count." 


\section{Unemployment}

eLancing in Sribulancer.com make available opportunities for those who are unemployed without further interviews. Some of the testimonials are listed below:

"To be a bachelor degree without job is really frustrating but sribulancer.com saved my life and give me the chance to a wide range of employment and self-development"

"After I got fired from my company, I thought my life was over, until one of my friend referring Sribulancer.com to me and I was learning fast finally I can continue my life."

"I conduct eLancing to explore more job possibilities without the fear of being rejected."

\section{Satisfaction and Passion}

eLancing enables eLancer to gain satisfaction from their job and they are free to choose the job as per their passion for example translating, composing web articles, data input, website creation and many more. The challenge in completing the project results in satisfaction for the eLancers. Some respondents stated that:

“...I love to be self-employed .... to work on things I love on various projects, I will never be bored."

"I experience a great satisfaction when I was able to solve my last project. It was so difficult but yet I found a way to accomplish a success."

\section{Networking}

Many eLancers said that Sribulancer.com offers them the opportunity to open and build new network which may lead to a new job gaining in present days or even in the future. These are some of their testimonials:

"eLancing at Sribulancer.com provide me a great array of networks which allow me to get more job in the future."

"eLancers should also focus on building networks to their employers since I experienced myself that more networks open the access to a permanent employment in real life, outside the online platform."

"Networking has always been one of my reason to engage in eLancing, since I am well aware that good networking will always grows you larger in your career."

Human Capital is defined by the OECD as the knowledge, skills, competencies and attributes embodied in individuals that facilitate the creation of personal, social and economic well-being. [5]. For that reason it is clear that the theory of human capital plays a role in the interest of eLancers to join Sribulancer.com since most of the eLancers possess a least a bachelor degree or related experience to be able to perform the particular task they applied for. In this terms eLancing in Sribulancer.com increases the human capital itself by experience they obtained in the job.

Work-family balance, flexibility and autonomy,economic incentives,skills development,trust and transparency,unemployment,passion and satisfaction, networking, all these reasons are representing extrinsic and intrinsic factors for eLancers o fulfill their needs, according to Self Determination Theory (STD). Consequently, it may be concluded that STD is related to eLancing motivation because by conducting eLancing, eLancer will feel a sense of contentment and satisfaction when their requirements are completed.

In correlation to Goal Achievement Theory, eLancing apparently deliver a prospect to develop e Lancer skills regularly. For example when they bid on a more complex task, automatically they have prepare more or even learn more before conducting the task, during the working process they might reveal something new or update their knowledge. All this cycle resulting in skill escalation, moreover since eLancers commonly like to explore new jobs, the possibility to earn various skill enhancement is wide open. 


\section{CONCLUSION}

Eight (8) primary motivations of eLancing such as work-family balance, flexibility and autonomy,economic incentives,skills development,trust and transparency,unemployment,passion and satisfaction, networking in Sribulancer.com, an online freelancing platform proves how eLancing has been and will continue to be a growing trend in Indonesia, as well as many other countries in the world. All the factors exposed have a correlation with 3 theories regarding motivation which are Human Capital Theory, Self Determination Theory and Goal Achievement Theory.

\section{REFERENCES}

[1] techinasia.com, “https://www.techinasia.com,” [Online]. Available: .( https:/www.techinasia.com/work-from-home-indonesia-elanceodesk-freelancer-online-designcopywriting-language-teaching-fiverr.

[2] merdeka.com, "https://www.merdeka.com," [Online]. Available: https://www.merdeka.com/teknologi/pekerja-freelance-bakal-menjadi-tren-di-indonesia.html). .

[3] CRSE, The Handbook Of Research On Freelancing And Self- Employment, Ireland: Senate Hall Acadmic Publishing, 2015.

[4] sribulancer.com, “.(https://www.sribulancer.com/),” [Online]. Available: .(https://www.sribulancer.com/).

[5] OECD, “The Value of People," OECD Insight, 2016.

[6] L. Legault, "Self-Determination Theory," Springer International Publishing , p. 2, 2017.

[7] A. J. M. M. A. B. M. J. F. R. \&. Elliot, "The effect of redon avoidance behavior in achievement contexts," Personality and Social Psychology, p. 365-375, 2015.

[8] A. \&. M. H. Elliot, “achievement,” J Pers Soc Psychol, pp. 501-519., 2016.

[9] researchgate.net, “(https://www.researchgate.net," [Online]. Available: (https://www.researchgate.net/publication/257471840_ELancing_A_review_and_research_agenda_f or_bridging_the_science-practice_gap.

[10 M. Bengtsson, "How to plan and perform a qualitative study using content analysis," NursingPlus

] Open, 2016.

[11 Writing@CSU, “https://writing.colostate.edu,"2019. [Online]. Available:

] https://writing.colostate.edu/guides/page.cfm?pageid=1307\&guideid=61. [Diakses 21st February 2019].

[12 N. S. Cohen, “Cultural work as site of struggle: freelancers and exploitation,” Triple C, 2017. ]

[13 Mostofa, "pekerja lepas (freelancer) dalam dunia bisnis," mozaik, 2018.

$$
\text { ] }
$$

[14 freelancer.com, "freelancer.com annual report 2016," freelancer limited ACN $141959042,2016$. ]

[15 deloitte.com, "The Rise Of The Social Enterprise 2018 Deloitte Global Human Capital Trends,"

] Deloitte Insight, USA, 2018 .

[16 A. Umiar, "Individual Work Behavior In Online Labor Markets: Temporality And Job Satisfaction,"

] OpenSym 17 Companion, 2017.

[17 R. S. -. M. b. -. O. K. O. -. P. A. -. D. Welch, “Decoding Global Talent," The Bostn Consulting

] Group. Inc. 2018. All Rights Reserved, USA, 2018.

[18 B. N. \&. R. H. Fareesa Malik, "Understanding The Development Implications Of Online

] Outsoursing: A Study Of Digital Labour Platfroms In Pakistan," Center For Development Informatics Global Development Institute, SEED, Manchester UK, 2018 . 
[19 Freelancer Limited, "Freelancer Limited Annual Report," Freelancer Limited, USA, 2015 .

]

[20 D. S. John Kitiching, “Are Freelancer a Neglected From Of Small Business,” Journal Of Small

] Business And Enterprise Development, 2012.

[21 Upwork.com, A Freelancer's Guide to Upwork, Upwork.com , 2017.

]

[22 Ai Group Workforce Development, "The Emergence Of The Big Economy Thought Leader Paper:

] Education \& Training Policy Team,” Ai Group Workforce Development, 2016 .

[23 Deloitte, “2018 Deloitte Millennial Survey Millennials Disappointed In Business, Unprepared For

] Industry 4.0," Deloitte.com, USA, 2108.

[24 C. Capital, "Human Capital," Springer-Verlag. Forthcoming , 2014. ]

[25 McKinsey\&Company, "McKinsey Global Institute Independent Work: Choice, Necessity, And The ] GIG Economy," McKinsey \& Company 2016, USA, 2016.

[26 D. H. Bridget Young, Introduction To Qualitative Research Methods, UK: Miror Methods In ] Research On Research, 2017.

[27 F. A. ,. f. B. Cristiano Codagnone, “The future Of Work In The 'Sharing Economy,” European ] Commission, 2016.

[28 J. Mason, Qualitative, London: SAGE Publications, 2009.

]

[29 B. S. A. Mohammed Abubakar, "Elancing Motivation,” Online Information Review, 2017. ]

[30 M. K. G. V. K. B. S. K. Rajat Kathuria, "Future Of Work In a Digital Era: The Potential And

] Challenges For Online Freelancing And Microwork In India," Indian Council For Research On International Economic Relations, 2017.

[31 A. Burke, “The Role Of Freelancers In The 21ST Century British Economy," PCG The Voice Of

] Freelancing, UK, 2015.

[32 APAC , "2018 APAC Workforce Insights Gig Economy: How Free Agents Are Redefining Work,"

] Persol Kelly, Singapore, 2018.

[33 G. F. C. V. Lehdonvirta, "Platform Sourcing How Fortune 500 Firms Are Adopting Online

] Freelancing Platforms," Oxford Internet Institute University Of Oxford August 2017 , UK, 2017.

[34 K. Ray, “Online Outsourcing And The Futuer Of Work,” Mercatus Center George Mason

] University, Virginia, USA, 2017.

[35 B. H. T. Shneikat, Motivational Factors For eLancing: Evidence From Turkey, Turkey : Eastern

] Mediterranean University, 2016.

[36 ILO Office For Indonesia And Timor-Leste, Indonesia Jobs Outlook 2017 Harnessing Techonolgy

] For Growth And Job Creation, Jakarta: ILO Office For Indonesia And Timor-Leste , 2017.

[37 Centre For The New Economy And Society , “The Future Of Jobs Report 2018," World Economic

] Forum, Switzerland, 2018.

[38 UNCTAD, "Word Investment Report 2107 Investment And The Digital Economy," dalam United

] Nations Conference On Trade And Development, 2017.

[39 i. M. Rebecca Florisson, "Platform: Types And Implications For Work And Employment -

] Literature Review," Eurofound , 2017.

[40 C. Goldin, "Human Capital," Springer-Verlag, forthcoming., 2014 .

]

[41 K. Jenkins, To Be Or Not To Be a Freelancer: Job Satisfaction And Wellbeing, london: Ipse, 2017. ]

[42 D. Laing, "Self-Employment," Agcas, Manchester, 2015.

] 
[43 B. R. A. M. Megee, "Exploring Online And Offline Informal Work: Findings From The ] Enterprising And Informal Work Activities (EIWA) Survey," Finance And Economics Discussion Series Divisions Of Research \& Statistics And Monetary Affairs Federal Reserve Board, Washington, D.C., Washington, D.C., 2016.

[44 A. S. \&. M. Orel, "The Role Of Vreative Hubs In The Freelancer Labour Market," Creative Hubs, ] 2016 .

[45 S. Davids, “The Relationship Between Self-Efficacy, Goal-Setting and Achievement Motivation ] Among Final Year Students at A Selected University in The Western Cape Province," University of the Western Cape, Western Cape, 2015.

[46 J. Kitching, "Exploring the UK freelance workforce in 2015," Small Business Research Centre

] Kingston University London, London, 2016.

[47 G. G. F. Zhu, "Trust And Disintermediation Evidence From An Online Freelance Marketplace,"

] Working Paper 18-103, 2018. 